\title{
Application of Hydrous Bismuth Oxide for Arsenic Removal from Aqueous Solutions
}

\author{
Manish Ranjan*†, Prabhat Kumar Singh* and Arun Lal Srivastav** \\ *Department of Civil Engineering, Indian Institute of Technology (BHU), Varanasi, India \\ **Chitkara University School of Engineering and Technology, Chitkara University, Himachal Pradesh, India \\ †Corresponding author: Manish Ranjan; manish040533@gmail.com
}

Nat. Env. \& Poll. Tech.

Website: www.neptjournal.com

Received: 10-04-2020

Revised: $02-06-2020$

Accepted: 04-06-2020

Key Words:

Arsenic removal

Metal pollution

Hydrous bismuth oxide

Langmuir isotherm

XRD; SEM

\begin{abstract}
The present study is devoted to arsenic sorption on hydrous bismuth oxide (HBO) through batch and column studies. Advantage of the adsorbent includes arsenic removal in addition to the simultaneous removal of nitrate and fluoride from aqueous solution. Both the forms of arsenic tested by adsorbent in which affinity for arsenic (V) was found better than arsenic (III). Langmuir isotherm and pseudo-secondorder kinetic models were found a fit with the experimental data. Calculation of adsorption energy and increased level of chloride in treated water indicated the possible role of physical adsorption and ion exchange phenomenon in arsenic $(\mathrm{V})$ sorption. A fixed bed column study gave $615 \mathrm{~mL}$ of treated water [As $(\mathrm{V}) \leq 0.01 \mathrm{mg} / \mathrm{L}]$ from $0.085 \mathrm{mg} / \mathrm{L}$ arsenic $(\mathrm{V})$ spiked influent with a sorption potential of 13.1-19.6 $\mu \mathrm{g} / \mathrm{g}$. XRD and EDS analyses confirmed the adsorption of arsenic (V) and the presence of chloride in the exhausted bed of adsorbent. The thermodynamic parameter has shown the endothermic and spontaneous process of adsorption.
\end{abstract}

\section{INTRODUCTION}

Groundwater is a major source of drinking water and its per capita availability is getting reduced over the last decades because of chemical contamination, hence its quality needs to be protected. Arsenic is one of the major groundwater contaminants widely found in the eastern regions of Indian sub-continents (Nath et al. 2008). Due to the adverse health effects including carcinogenic nature (Sarkar \& Paul 2016), the maximum allowable concentration of arsenic in drinking water set by United States Environmental Protection Agency (UPSEA) is $0.01 \mathrm{mg} / \mathrm{L}$ (Iesan et al. 2008). World Health Organization also recommended the maximum permissible limit of arsenic as $0.01 \mathrm{mg} / \mathrm{L}$ in drinking water (Vaclavikova et al. 2008). Hence, excess of arsenic in ground water used for drinking is toxic to humans and could be taken as serious threat for human health (Srivastav \& Ranjan 2020). The removal of arsenic by adsorption process was studied in the present paper.

Arsenic is a semi-metal and commonly found in four oxidation states of $+5,+3,0,-3$. Inorganic arsenic acids or arsenates $\left(\mathrm{H}_{3} \mathrm{AsO}_{4}, \mathrm{H}_{2} \mathrm{AsO}_{4}^{-}, \mathrm{HAsO}_{4}^{2-}\right.$ and $\left.\mathrm{AsO}_{4}^{3-}\right)$ are found in the oxidation state of +5 and collectively referred as $\mathrm{As}(\mathrm{V})$, whereas arsenous acids or arsenites $\left(\mathrm{H}_{3} \mathrm{AsO}_{3}, \mathrm{H}_{2} \mathrm{AsO}_{3}^{-}\right.$, $\mathrm{HAsO}_{3}^{2-}$ and $\mathrm{AsO}_{3}^{3-}$ ) are found in the oxidation state of +3 and collectively referred as As(III) (Zhou et al. 2017). The solubility of arsenic is greatly affected by $\mathrm{pH}$ of the solution (Mudhoo et al. 2011). Arsenic (V) predominates as $\mathrm{H}_{3} \mathrm{AsO}_{4}$ in aerobic waters (high redox potential) with lower $\mathrm{pH}(<2)$ whereas arsenic species $\mathrm{H}_{2} \mathrm{AsO}_{4}^{-}$and $\mathrm{HAsO}_{4}^{2-}$ are found in $\mathrm{pH}$ range of 2-11 as shown in Fig. 1 (Khan et al. 2004). Similarly, arsenic (III) exists as $\mathrm{H}_{3} \mathrm{AsO}_{3}$ at low $\mathrm{pH}(<3)$ but gets easily replaced by $\mathrm{H}_{2} \mathrm{AsO}_{3}^{-}$as the $\mathrm{pH}$ increases beyond 9.2 and further at high $\mathrm{pH}(>12)$, only $\mathrm{HAsO}_{3}^{2-}$ can be observed in water as shown in Fig. 1 (Mudhoo et al. 2011). Hence, pH is one of the prime factors for redox equilibrium (Fig. 1) between arsenic (V) and arsenic (III) thus, arsenic speciation and its mobility is greatly affected by $\mathrm{pH}$ as well as the redox potential (Doušova et al. 2003). But, oxygen present in air leads to an increase in the redox potential of the groundwater when it is exposed to the open atmosphere. Consequently, arsenic (III) immediately changes into arsenic (V) (Ngai et al. 2006). Hence, arsenic (V) is a dominant species over arsenic (III) in an oxidative environment (Sarkar \& Paul 2016). The major component of arsenic (V) in aqueous environment are anionic species $\left(\mathrm{H}_{2} \mathrm{AsO}_{4}^{-}, \mathrm{HAsO}_{4}^{2-}\right.$ and $\left.\mathrm{AsO}_{4}^{3-}\right)$ and mostly found in the $\mathrm{pH}$ range of 6-8 as reported by Ngai (2002).

Adsorption process is one of the widely applied methods to remove arsenic from water due to its simplicity (Bhatnagar \& Sillanpaa 2011). Many inorganic adsorbents are investigated for water treatment because organic 


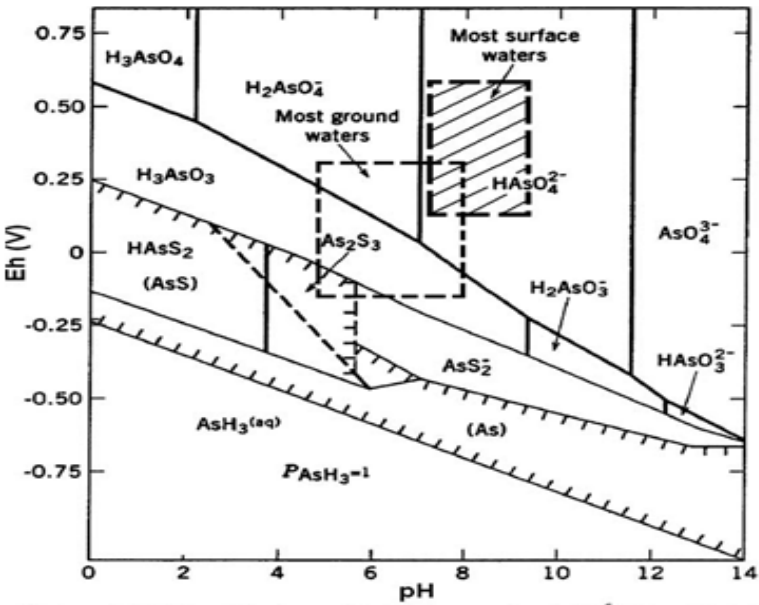

Notes: $25^{\circ} \mathrm{C}$ and $1 \mathrm{~atm}$ with total arsenic at $10^{-5} \mathrm{M}$ and total sulphur at $10^{-3} \mathrm{M}$. Solid species are enclosed in parentheses in cross-hatched area, which indicates solubility less than $10^{-5.3} \mathrm{M}$

Fig. 1: Eh-pH diagram for arsenic (Mudhoo et al. 2011)

adsorbents reported to have fouling problems (Ustun et al. 2007). In the water, it is observed that metal oxide has a high affinity towards negatively contaminates (Yao et al. 2011). Several researchers have examined the application of hydrous metal oxide (HMO) as adsorbents for arsenic remediation from aqueous solutions. Hydrous metal oxides (HMOs) are amongst the largest group of studied inorganic materials because of having advantages like suitability for sorptive filtration and ease in regeneration and reuse. Among various metal oxides the oxide of titanium (Wagle \& Shipley 2016), iron (Puente-Urbina \& Montero-Campos 2017), activated alumina (Sinha et al. 2011), zinc (Li et al. 2011), aluminium (Park et al. 2012) and zirconium (Chaudhry et al. 2017) have been reported with good arsenic sorption capacity from water. Researchers have also used mixed oxides like Fe-Ti (Gupta \& Ghosh 2009), Ce-Ti (Li et al. 2010), Fe-Zr (Ren et al. 2011), Fe-Cr (Basu \& Ghosh 2011), Fe-Al (Basu et al. 2012), Fe-Cu (Zhang et al. 2013), Fe-Mn (Kong et al. 2014), Mn-Al (Wu et al. 2017), Zr-Ti (Anđelković et al. 2017), Fe-Ti-Mn composite oxide (Zhang et al. 2018), $\mathrm{Fe} / \mathrm{Al}$ composite (Inchaurrondo et al. 2019) and $\mathrm{Fe}_{3} \mathrm{O}_{4} @$ $\mathrm{TiO}_{2}$ sheets nanocomposite (Deng et al. 2019) for the same.

A thorough literature review reveals that hydrous metal oxide has been used by many researchers for the removal of arsenic from water. Recently, hydrous bismuth oxide (HBO) is reported to have excellent and promising adsorptive properties of nitrate and fluoride sorption from aqueous solution. Initially, Fritsche (1993) found sorptive property of yellow bismuth hydroxide for nitrate removal. Further, Singh (1999) investigated the potentials of various bismuth compounds for nitrate removal from aqueous solution due to the ion exchange of nitrate with embedded chloride of
HBO. Hydrous Bismuth Oxide (HBO) is the precipitated product of bismuth trioxide in the presence of strong acid with a strong base. A ratio of 1:1 is used to make precipitate, which is designated as HBO1, similarly $1: 2$ and 1:3 named as $\mathrm{HBO} 2$ and $\mathrm{HBO} 3$ respectively. Excess of strong base results in polymerizations of $\mathrm{HBO}$ as reported by Ranjan et al. (2019). HBO2 and HBO3 are the final polymeric products of hydrous bismuth oxides which have excellent nitrate removal efficiency (82\%) at the initial nitrate concentration of $62 \mathrm{mg}$ $\mathrm{NO}_{3}{ }^{-} / \mathrm{L}$ (Singh et al. 2012). Further, Srivastav et al. (2014) reported a maximum sorption potential of $0.992 \mathrm{mg} \mathrm{NO}_{3}{ }^{-} / \mathrm{g}$ by $\mathrm{HBO} 2$ with $62 \mathrm{mg} \mathrm{NO}_{3}{ }^{-} / \mathrm{L}$ initial concentration in batch experiments. In another study, Singh et al. (2015) reported $0.974 \mathrm{mg} \mathrm{NO}_{3}{ }^{-} / \mathrm{g}$ nitrate sorption using $\mathrm{HBO} 3$ at neutral $\mathrm{pH}$. Srivastav et al. (2013) observed that HBO1 has $0.196 \mathrm{mg}$ $\mathrm{F}^{-} / \mathrm{g}$ sorption potential at $20 \mathrm{mg} \mathrm{F}^{-/} \mathrm{L}$ initial concentration. However, $\mathrm{HBO} 2$ could remove only $51 \%$ fluoride at $10 \mathrm{mg}$ $\mathrm{F}^{-} / \mathrm{L}$ of initial concentration with $100 \mathrm{~g} / \mathrm{L}$ adsorbents Srivastav et al. (2015). To increase the anionic sorptive potential of HBO powders, Ranjan et al. (2015); (2019) prepared $\mathrm{HBO} 2$ adsorbent in the presence of varying concentrations of cations like $\mathrm{Fe}, \mathrm{Ca}, \mathrm{Mg}$ and $\mathrm{Cu}$. This leads to increase the fluoride removal efficiency by $31 \%$ when $\mathrm{HBO} 2$ prepared in presence of $0.1 \mathrm{M} \mathrm{MgCl}_{2}$ with respect to unamended $\mathrm{HBO}$, whereas, $\mathrm{HBO} 2$ in presence of $0.07 \mathrm{M} \mathrm{FeCl}_{3}$ found gainful to increase the nitrate sorption potential. Characterization of prepared materials has confirmed the presence of cationic ligands in the matrix of $\mathrm{HBO} 2$ material. Hence, the material exhibited high adsorption capacities towards nitrate $\left(\mathrm{NO}_{3}{ }^{-}\right)$ and fluoride $\left(\mathrm{F}^{-}\right)$.

Based on the affinity exhibited by hydrous bismuth oxide towards major anionic contaminants (i.e., nitrate and fluoride) the possibility of arsenic removal from aqueous solution was tested and discussed in the present study. Adsorption behaviour of arsenic (V) and arsenic (III) by hydrous bismuth oxide (HBO1) was compared by keeping them under the same condition (Fig. 2).

Of both, arsenic (III) and arsenic (V) removals were examined by HBO1 under similar condition. But, removal efficiency for arsenic $(\mathrm{V})$ was found to be $16.5 \%$ greater than arsenic (III). Lower adsorption of arsenic (III) can be better correlated to the uncharged (Fig. 2) form of arsenic species in environment relevant $\mathrm{pH}$ (Zhu et al. 2016). Hence, arsenic (V) removal using HBO1 was chosen for further experiments during the present study.

\section{MATERIALS AND METHODS}

\section{Arsenic Solutions}

$4.1601 \mathrm{~g}$ of sodium arsenate $\left(\mathrm{Na}_{2} \mathrm{HAsO}_{4} \cdot 7 \mathrm{H}_{2} \mathrm{O}\right.$, E. Mark, 


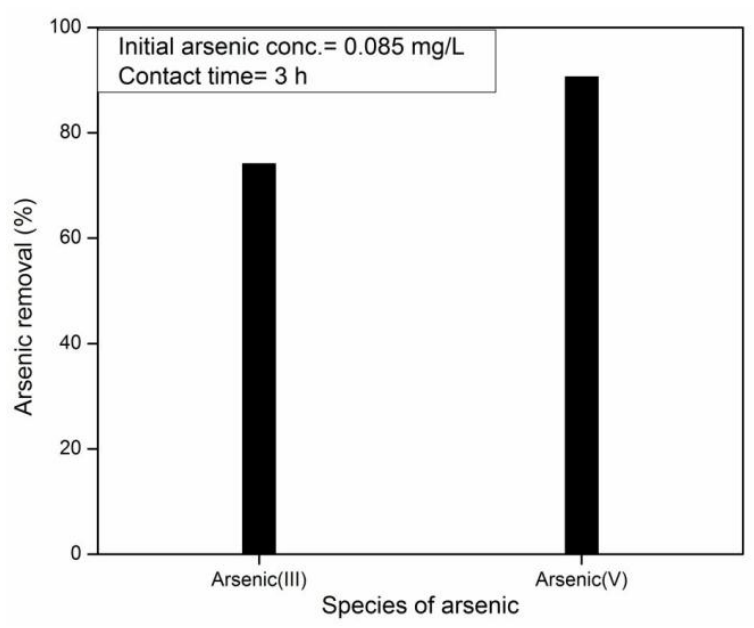

Fig. 2: Percentage removal of arsenic.

Germany) was dissolved in one litre of double distilled water in order to make $100 \mathrm{mg} / \mathrm{L}$ stock solution of arsenic (V). Further dilution methods were used for making the working solutions of arsenic.

\section{Preparation of Hydrous Bismuth Oxide (HBO)}

Hydrous Bismuth Oxide (HBO) was prepared by using bismuth trioxide powder of commercial AR grade. $0.1 \mathrm{M}$ $\mathrm{Bi}_{2} \mathrm{O}_{3}$ was prepared by dissolving bismuth trioxide in $2 \mathrm{~N}$ $\mathrm{HCl}$ solutions and precipitated hydrous bismuth oxide was obtained as per the method reported by Singh et al. (2012). Three forms of HBOs designated as $\mathrm{HBO} 1, \mathrm{HBO} 2$ and $\mathrm{HBO} 3$ were prepared using $0.1 \mathrm{M} \mathrm{Bi}_{2} \mathrm{O}_{3}$ solution in $2 \mathrm{~N}$ $\mathrm{HCl}$ with successively increasing volumetric proportions of $2 \mathrm{~N} \mathrm{NaOH}$ in the ratio of $1: 1,1: 2$ and $1: 3$ respectively. The obtained precipitates were washed with distilled water till $\mathrm{pH}$ and chloride reduce to a minimum level. It is then kept in the oven drying at $103 \pm 2{ }^{\circ} \mathrm{C}$ for $24 \mathrm{~h}$ (Srivastav et al. 2015). HBO1 was visibly white in colour but yellow precipitate has been shown by $\mathrm{HBO} 2$ and $\mathrm{HBO} 3$. All three forms of Hydrous Bismuth Oxide (HBOs) was found better in the arsenate removal from water hence, $\mathrm{HBO} 1$ was selected for further study due to less cost of synthesis.

\section{Measurement of Arsenic Concentration}

Arsenator (Model No: Wag-WE10500 made by Wag-Tech, England) was used for determination of arsenic concentration in aqueous solutions.

The performance of adsorbent for arsenic removal was calculated by using equation (1):

$$
\text { Arsenic removal }(\%)=\frac{(\mathrm{Co}-\mathrm{Ce})}{\mathrm{Co}} \times 100
$$

Where, $\mathrm{C}_{\mathrm{o}}$ and $\mathrm{C}_{\mathrm{e}}$ are the initial and final concentrations of arsenic in $\mathrm{mg} / \mathrm{L}$.
Experiments with triplicate samples were carried out in at a controlled temperature of $25 \pm 2{ }^{\circ} \mathrm{C}$ and an average value is reported. Digital $\mathrm{pH}$ meter was used for the determination of $\mathrm{pH}$. Sulphate, chloride and alkalinity (bicarbonate) were determined by titration method as given in Standard Method (Clesceri et al. 2005). Bismuth ion in treated water was determined by Atomic Absorption Spectrophotometer (Model AAS4141, ECIL, India).

\section{Batch Experiment}

A standard solution of $0.10 \mathrm{mg} / \mathrm{L}$ of arsenic (V) concentration was prepared from stock solution. Powder dosage of $6 \mathrm{~g} / \mathrm{L}$ was taken with continuous stirring for 180 minutes. Finally, the powder was removed by using Whatman 42 filter paper and determination of $\mathrm{pH}$, remaining arsenic, and chloride concentrations were carried out for filtrate. For kinetic studies, $100 \mathrm{~mL}$ of $0.05,0.10,0.15,0.20$ and $0.25 \mathrm{mg} / \mathrm{L}$ arsenic solution was taken for varying contact time from 60 to 360 minutes with $6 \mathrm{~g} / \mathrm{L}$ adsorbent dosage at $298 \mathrm{~K}$. After 60 minutes of time interval, the filtrate was collected through Whatman 42 and $\mathrm{pH}$, remaining arsenic and chloride was determined. Equilibrium studies were carried out on varying initial arsenate concentration from 0.05 to $0.25 \mathrm{mg} / \mathrm{L} .100$ $\mathrm{mL}$ of $0.05,0.10,0.15,0.20$ and $0.25 \mathrm{mg} / \mathrm{L}$ arsenic solution, with an initial neutral $\mathrm{pH}$ condition at temperatures of 298 , 308 and $318 \mathrm{~K}$ were mixed with an adsorbent dose of $6 \mathrm{~g} / \mathrm{L}$ with contact period of 180 minutes in agitating condition.

\section{Column Experiment}

The particle size of $\mathrm{HBO} 1$ powder is very fine and to use in column adsorption study, HBO1 powder and sand was mixed in the ratio of 1:4 $(\mathrm{w} / \mathrm{w})$. The sand was initially soaked in $0.1 \mathrm{~N} \mathrm{HCl}$ for $24 \mathrm{~h}$ and then washed with sufficient distilled water. A glass column was filled up to the height of around $12 \mathrm{~cm}$ with the mixed media $\left(\mathrm{d}_{10}=0.18, \mathrm{C}_{\mathrm{u}}=\mathrm{D}_{60} / \mathrm{D}_{10}=2.4\right.$, $\mathrm{pH} \sim 7.0$ ). A simulated solution of $0.085 \mathrm{mg} / \mathrm{L}$ arsenic (V) was taken for column study which resembles with the level of arsenate present in groundwater of our country. The arsenic contaminated water was passed with a flow rate of $1.23 \mathrm{~mL} / \mathrm{min},(\mathrm{EBC}=30.65$ minutes $)$. The samples of effluents were collected at a scheduled time interval and used for the determination of $\mathrm{pH}$, chloride and arsenic concentration.

\section{Characterization}

To diagnose chemical species and structural arrangement of adsorbent (HBO1), the characterization was carried out using X-ray diffraction (XRD), Scanning electron microscopy (SEM) and energy-dispersive X-ray spectroscopy (EDS). The information about possible structural compound formed could be obtained from the X-ray diffraction pattern by X-ray 
diffraction (Philips, Netherlands, 1710). Surface morphology and elemental analysis have been done by SEM and EDS (ZEISS EVO 18 Model-2045, Industrial Measurements and Medical Devices, Germany).

\section{RESULTS AND DISCUSSION}

\section{Batch Experiment for Arsenic (V) Removal}

The results of As (V) removal using hydrous bismuth oxide (HBO1) from aqueous solutions with $0.10 \mathrm{mg} / \mathrm{L}$ initial arsenic $(\mathrm{V})$ concentration are given in Table 1.

Excellent removal efficiency (> 90\%) of arsenic was observed using HBO1 powder is a significant finding of the present observations with $0.10 \mathrm{mg} / \mathrm{L}$ initial concentration in groundwater. The obtained $\mathrm{pH}$ water quality after treated water was in the range 8.3-8.5 indicating hydroxide ions were not eluted during As(V) adsorption. Hence hydroxide ions are not competing for anions for arsenic sorption on
HBO1. Chloride could be caustic agent for As(V) removal. Chloride seems to attach with the bismuth as loose bond and could be able to go for transitional exchange with As(V) under suitable condition, whereas hydroxide strongly boned with bismuth and couldn't avail changes. Similar results were demonstrated by Ruixia et al. (2002) and Singh et al. (2012) with highlighting an elevated level of chloride in the effluent. Park et al. (2008) concluded the fluoride and nitrate sorption by cement paste column as the result of ion exchange mechanism.

\section{Effect of Adsorbent Dosage}

The effects of adsorbent dosage on $\mathrm{As}(\mathrm{V})$ removal and final $\mathrm{pH}$ were also studied and it ranges from 1 to $10 \mathrm{~g} / \mathrm{L}$ with 180 minutes of contact time and $0.10 \mathrm{mg} / \mathrm{L}$ of initial As(V) concentration.

From Fig. 3a, it is observed that $6 \mathrm{~g} / \mathrm{L}$ dosage was optimum for As(V) removal using HBO1 adsorbent.

Table 1: arsenic (V) sorption at different adsorbent dosage.

\begin{tabular}{|c|c|c|c|c|c|c|c|c|}
\hline \multirow{2}{*}{$\begin{array}{l}\mathrm{S} \\
\text { No. }\end{array}$} & \multirow{2}{*}{$\begin{array}{l}\text { Dosage of } \\
\text { HBO1 } \\
(\mathrm{g} / \mathrm{L})\end{array}$} & \multicolumn{2}{|c|}{ Water quality before treatment } & \multicolumn{3}{|c|}{ Water quality after Treatment } & \multirow{2}{*}{$\begin{array}{l}\text { Removal } \\
\text { efficiency } \\
(\%)\end{array}$} & \multirow{2}{*}{$\begin{array}{l}\text { Chloride Exchange Ratio } \\
=\text { Chloride eluted/ } \\
\text { Arsenic sorbed }\end{array}$} \\
\hline & & $\mathrm{pH}$ & $\begin{array}{l}\mathrm{Cl}^{-} \\
(\mathrm{mg} / \mathrm{L})\end{array}$ & $\mathrm{pH}$ & $\begin{array}{l}\mathrm{As}(\mathrm{V}) \\
(\mathrm{mg} / \mathrm{L})\end{array}$ & $\begin{array}{l}\mathrm{Cl}^{-} \\
(\mathrm{mg} / \mathrm{L})\end{array}$ & & \\
\hline 1. & 1 & 7.3 & 6.6 & 8.38 & 0.034 & 27 & 66 & 0.56 \\
\hline 2. & 2 & 7.2 & 6.6 & 8.40 & 0.023 & 22 & 77 & 0.56 \\
\hline 3. & 3 & 7.3 & 6.6 & 8.43 & 0.019 & 30 & 81 & 0.61 \\
\hline 4. & 4 & 7.4 & 6.6 & 8.40 & 0.012 & 31 & 88 & 0.59 \\
\hline 5. & 5 & 7.3 & 6.6 & 8.46 & 0.007 & 33 & 93 & 0.60 \\
\hline 6. & 6 & 7.4 & 6.6 & 8.52 & 0.006 & 37 & 94 & 0.62 \\
\hline 7. & 7 & 7.5 & 6.6 & 8.34 & 0.006 & 32 & 94 & 0.64 \\
\hline 8. & 8 & 7.3 & 6.6 & 8.46 & 0.006 & 31 & 94 & 0.62 \\
\hline 9. & 9 & 7.6 & 6.6 & 8.44 & 0.006 & 33 & 94 & 0.64 \\
\hline 10. & 10 & 7.5 & 6.6 & 8.47 & 0.006 & 28 & 94 & 0.62 \\
\hline
\end{tabular}

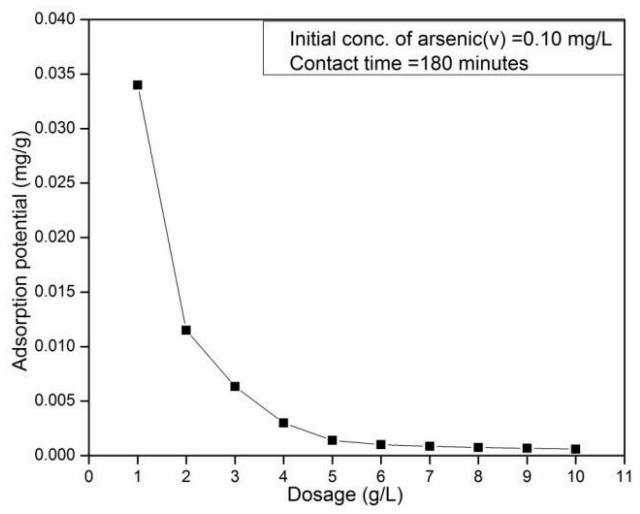

(a)

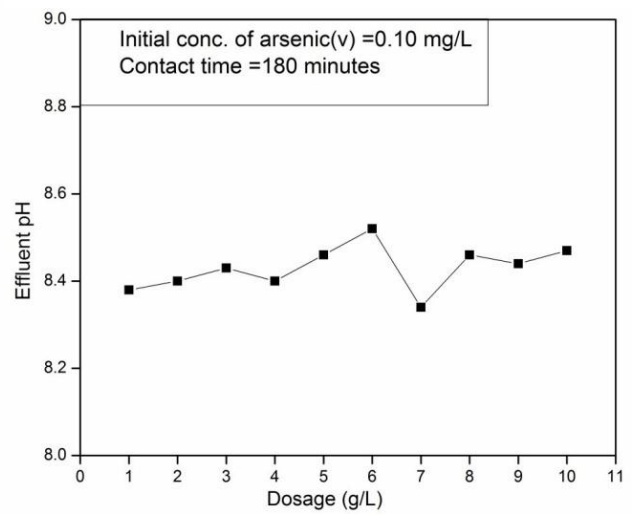

(b)

Fig. 3(a): Variation of adsorbent dosage on As(V) sorption. 3(b): Variation of adsorbent dosage on effluent pH. 
Abundant numbers of adsorption sites are available at low dosages, but at higher dosages overlapping of active sites may reduce the effective surface area of adsorbent (Luther et al. 2012). Hence, further experiments were done by considering $6 \mathrm{~g} / \mathrm{L}$ as optimum dosage for $\mathrm{As}(\mathrm{V})$ sorption.

Fig. $3 \mathrm{~b}$ shows the treated water $\mathrm{pH}$ on $\mathrm{As}(\mathrm{V})$ removal with different dosages of $\mathrm{HBO} 1$ powder. It is observed that the solution $\mathrm{pH}$ did not get affected significantly due to $\mathrm{As}(\mathrm{V})$ removal by $\mathrm{HBO} 1$ in aqueous solution. Similar observations have been reported by Srivastav et al. (2014) and Singh et al. (2015) in his study for nitrate sorption by HBO2 adsorbent.

\section{Effect of Contact Time}

The variation of contact time on the adsorption of $\mathrm{As}(\mathrm{V})$ from the water was studied by taking five initial concentrations $(0.05,0.10,0.15,0.20$ and $0.25 \mathrm{mg} / \mathrm{L})$ of $\mathrm{As}(\mathrm{V})$ by hydrous bismuth oxide (HBO1). The contact time ranged from 60 to 360 minutes (Fig. 4a) and a time interval of 60 minutes was selected for samples collection.

Initially, $70-80 \%$ of removal was reported in the initial contact time of 180 minutes and further, the rate of removal became slow or insignificant. During the initial stage, large numbers of active sites are available for adsorption but as the reaction progresses, the active sites are no longer available to occupy because of saturation (Swain et al. 2012). Hence, 180 minutes considered to be the optimum contact time for arsenic removal from aqueous solution for further studies. It was confirmed by Singh et al. (2015) with experimental data showing the maximum adsorption took place in the first 180 minutes of contact time.

\section{Chloride Exchange Ratio (CER)}

The effluents were found to have elevated levels of chloride with respect to the influent. Hence, HBO1 may contain some amount of chloride sorbed in its material matrix, which could be exchanged with arsenic during sorption process. During equilibria study, apart from $\mathrm{As}(\mathrm{V})$ concentration, chloride level of treated water was also determined. Chloride Exchange Ratio (CER) may be defined as:

$\mathrm{CER}=$ Chloride eluted (meq/g)/arsenic $(\mathrm{V})$ taken up (meq/g)

An analysis of total As(V) sorbed and chloride eluted in the water at a different dose of hydrous bismuth oxide (HBO1) was carried out. It is observed that CER of hydrous bismuth oxide (HBO1) is found in the range of $0.59-0.64$. It indicates that possibly partial $\mathrm{As}(\mathrm{V})$ removal is through ion exchange mechanism with embedded chloride in HBO1 matrix. The nitrate removal experiment using yellow bismuth hydroxide and yellow hydrous bismuth oxide had been carried out by Fritsche (1993) and Singh et al. (2012) respectively. The authors emphasized the ion exchange mechanism responsible for nitrate sorption. No leaching of bismuth ion and increased concentration of chloride in treated water may be indicative of partial exchange of chloride with sorbed $\mathrm{As}(\mathrm{V})$ ions.

\section{Effect of Competitive Anions}

The presence of competitive ions bicarbonate (as alkalinity) and sulphate may hinder the adsorption of $\mathrm{As}(\mathrm{V})$ and because of this reason their effect has been also studied in the range from 1 to $5 \mathrm{meq} / \mathrm{L}$ (Fig. 4b) with $0.10 \mathrm{mg} / \mathrm{L}$ initial $\mathrm{As}(\mathrm{V})$ concentration level.

It can be noted that $\mathrm{As}(\mathrm{V})$ removal efficiency of $\mathrm{HBO} 1$ decreased in order as given below:

\section{Sulphate $>$ Bicarbonate}

The lower hydration energy of bicarbonate ion could be the reason for fast competing anions among bicarbonate $\left(\Delta \mathrm{G}^{\circ}=380-\mathrm{KJ} / \mathrm{mol}\right)$ and sulphate $\left(\Delta \mathrm{G}^{\circ}=-1,103 \mathrm{KJ} / \mathrm{mol}\right)$.

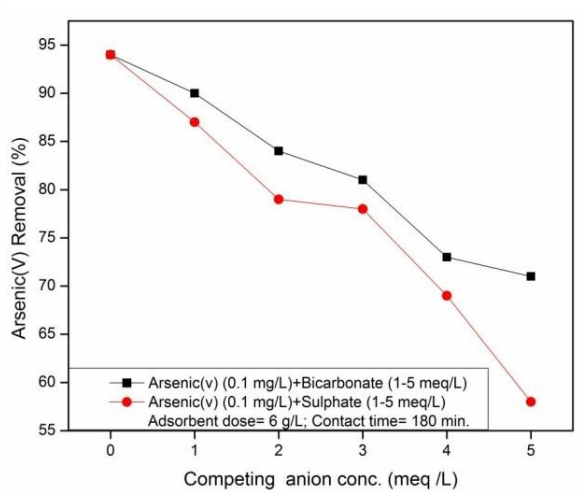

(b)

Fig. 4 (a): Effect of contact time on As(V) sorption. 4(b): Effect of competing anion on As(V) sorption. 
Hydration energy with low value has more affinity towards adsorption in comparison to the ions which has high hydration energy (Gu et al. 2004, Song et al. 2012).

\section{Column Experiments for As(V) Removal}

The column study has also been done for enhancing the field applicability of HBO1 adsorbent in water treatment. A glass column ( $2 \mathrm{~cm}$ diameter) was filled upto $12 \mathrm{~cm}$ depth with HBO1 powder mixed homogeneously with inert sand particles (1:4 ratio). As $(\mathrm{V})$ solution was passed through the column with an influent concentration of $0.085 \mathrm{mg} / \mathrm{L}$ and $1.23 \mathrm{~mL} / \mathrm{min}$ flow rate, which gave empty bed contact time (EBCT) as 30.65 minutes. Effluent samples were analysed for remaining $\mathrm{As}(\mathrm{V})$ concentration. The $\mathrm{pH}$ and breakthrough curve is shown in Fig. 5.

It is observed that the breakthrough of the column occurs around 500 minutes of duration after passing 615 $\mathrm{mL}$ of contaminated water, which gave a complete $\mathrm{As}(\mathrm{V})$ removal by consuming $13.1 \mu \mathrm{g} / \mathrm{g}$ of $\mathrm{HBO} 1$ adsorbent. The exhaustion point was found after 750 minutes after passing about $922 \mathrm{~mL}$ of contaminated water by consuming 19.6 $\mu \mathrm{g} / \mathrm{g}$ adsorbent. Hence, fixed bed column study using HBO1 as adsorbent produces $615 \mathrm{~mL}$ of drinking water $(\mathrm{As}(\mathrm{V}) \leq$ $0.01 \mathrm{mg} / \mathrm{L})$ free from $\mathrm{As}(\mathrm{V})(0.085 \mathrm{mg} / \mathrm{L})$ at inflow rate of $1.23 \mathrm{~mL} / \mathrm{min}$ and $\mathrm{pH} 7.0( \pm 0.1)$, which indicates the applicability of HBO1 for arsenic removal from the aqueous solution. In a similar study, Fritsche (1993) conducted experiments using yellow bismuth hydroxide in column study for nitrate and other anions removal experiment and found $93 \%$ of nitrate removal with $58.6 \mathrm{mg} / \mathrm{L}$ as influent nitrate concentration. Whereas in another study Singh et al. (2012) revealed the nitrate sorption through hydrous bismuth oxide (HBO2 and $\mathrm{HBO} 3$ ) in column study and reported the $5.31 \mathrm{mg} / \mathrm{g}$ and $6.2 \mathrm{mg} / \mathrm{g}$ of nitrate sorption capacity of adsorbent with $62 \mathrm{mg} / \mathrm{L}$ of nitrate as influent

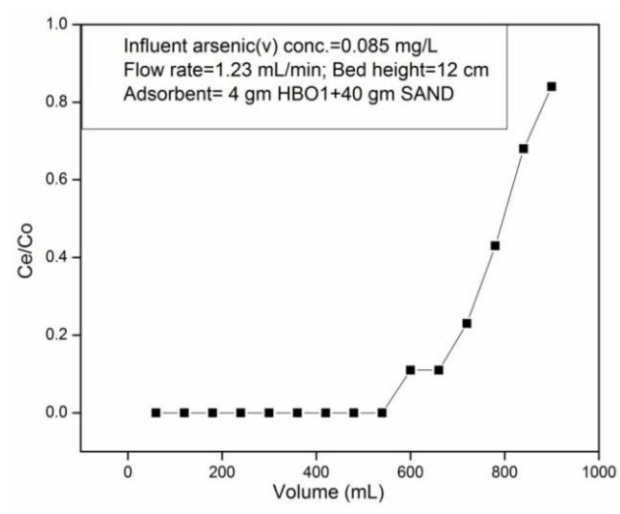

Fig. 5: As(V) sorption through column experiment. using $5 \mathrm{~g}$ of wet precipitate of yellow hydrous bismuth oxide each.

\section{Characterization}

XRD analysis: Fig. 6 shows the XRD pattern of HBO1 which exhibits many peaks at 2 theta values of $24^{\circ}, 26.2^{\circ}$, $29.57^{\circ}, 30.24^{\circ}, 32.72^{\circ}, 47.1^{\circ}$ and $57.2^{\circ}$. Crystalline nature of adsorbent was confirmed by the presence of sharp peaks (Ramli et al. 2007). Peaks corresponding to $2=29.57,30.24$ and 32.72 are related with $\mathrm{Bi}_{12} \mathrm{O}_{17} \mathrm{Cl}_{2}$ (File no-370702) as per the X-pert high score software (2009) which confirms the crystalline nature of $\mathrm{HBO} 1$. The observed composition of hydrous bismuth oxide $\left(\mathrm{Bi}_{12} \mathrm{O}_{17} \mathrm{C}_{12}\right)$ indicates the presence of chloride inside it and similar results were also observed by Srivastav et al. (2013).

SEM and EDS: The SEM image of HBO1 before and after $\mathrm{As}(\mathrm{V})$ adsorption was taken to know its surface characteristics with magnification: $50 \mathrm{~K}$ and $200 \mathrm{~nm}$ resolution (Fig. 7). The smooth surface and spherical nature of grains were found before adsorption but relatively high rough surface and angular grain were spotted after adsorption. The elemental analysis of the raw and exhausted adsorbent was also studied. The point of incidence of the spectrum and the resultant EDS spectrum for each test is attached and the elements found are shown in Fig. 7. Bismuth and chloride are the compositions of HBO1 before adsorption and but, after adsorption $\mathrm{As}(\mathrm{V})$ become an integral part of HBO1. This is probably due to the active chloride ion present in the matrix of adsorbent and with suitable condition its gets partially exchange with chloride and partially adsorbed in the rough surface of the adsorbent. Thus, appearance of As(V) in the exhausted adsorbent indicates that sorption of $\mathrm{As}(\mathrm{V})$ has possibly taken place on HBO1.

Kinetic studies: Kinetics studies have been conducted to evaluate the performance of a given adsorbent and mechanism

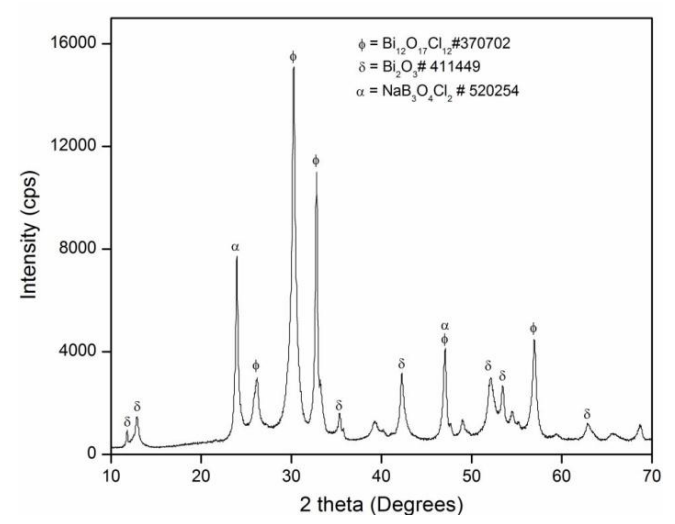

Fig. 6: XRD pattern of $\mathrm{HBO} 1$ powder. 


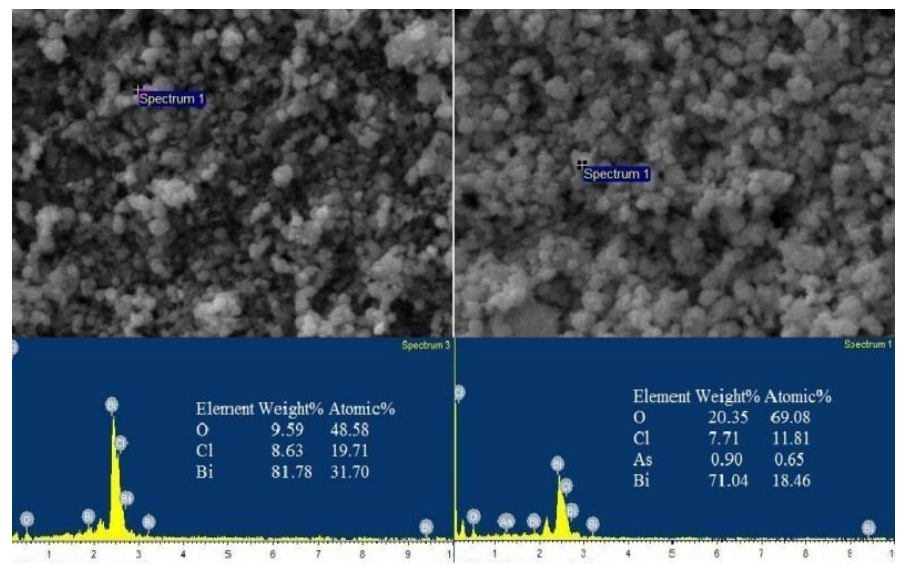

Fig. 7: SEM and EDS of HBO1 before and after adsorption.

of removal. In order to understand the sorption mechanism, three kinetic models have been applied with experimental results. Effect of five initial As(V) concentration (50, 100, $150,200,250 \mu \mathrm{g} / \mathrm{L})$ and variation in contact time ( 60 minutes to 360 minutes) was observed. It was noticed that most of the arsenic removal took place within $180 \mathrm{~min}$. and adsorption capacity increased from 4.8 to $36 \mu \mathrm{g} / \mathrm{g}$. Pseudo-first-order, Pseudo-second-order and Weber-Morris kinetic models were applied to validate experimental data and derived kinetics parameters are given in Table 2.

Pseudo-first order: Lagergren (1898) presented a first-order rate equation to describe the kinetic process of liquid solid phase adsorption as mentioned in eq (2):

$$
\log \left(q_{e}-q t\right)=\log q_{e}-\frac{K^{1}}{2.303 t}
$$

Where, $\mathrm{q}_{\mathrm{e}}$ and $\mathrm{q}_{\mathrm{t}}$ are adsorption capacity $(\mu \mathrm{g} / \mathrm{g})$ at equilibrium and at any time $\mathrm{t} ; \mathrm{K}_{1}=$ pseudo-first-order rate constant $\left(\right.$ time $\left.^{-1}\right)$. The linear interpolation of slope from the plots between $\log \left(\mathrm{q}_{\mathrm{e}}-\mathrm{q}_{\mathrm{t}}\right)$ versus $\mathrm{t}$ will give the adsorption rate constant $\left(\mathrm{K}_{1}\right)$. Fig. 8a presents the pseudo-first-order kinetic plot of $\mathrm{As}(\mathrm{V})$ sorption on HBO1 in aqueous solution. The plot of ' $\log \left(\mathrm{q}_{\mathrm{e}}-\mathrm{q}_{\mathrm{t}}\right)$ ' versus ' $\mathrm{t}$ ' was almost linear as it gave with rate constant $\left(\mathrm{K}_{1} \times 10^{-3}\right)$ of $2.303,4.606,4.606,4.606$ and
$2.303 \mathrm{~min}^{-1}$. The value of $\mathrm{K}_{1}$ showed the decreasing trend along with increasing initial $\mathrm{As}(\mathrm{V})$ concentration from 0.10 to $0.25 \mathrm{mg} / \mathrm{L}$. A similar conclusion was drawn by Pirila et al. (2011) using hydrous titanium dioxide as adsorbent for arsenic removal. The rate constant during observations were found as $3.26 \times 10^{-3}, 4.02 \times 10^{-3}$ and $3.96 \times 10^{-3}$ for arsenic sorption at $298 \mathrm{~K}$.

Pseudo-second order: The pseudo-second order adsorption kinetic model is given by Ho and McKay (1999) as given in eq. (3).

$$
\frac{\mathrm{t}}{\mathrm{qt}}=\frac{1}{\mathrm{~K}_{2} \mathrm{q}_{\mathrm{e}}^{2}}+\frac{\mathrm{t}}{\mathrm{q}_{\mathrm{e}}}
$$

Where, $\mathrm{q}_{\mathrm{e}}$ and $\mathrm{q}_{\mathrm{t}}$ are adsorption capacity $(\mu \mathrm{g} / \mathrm{g}$ ) at equilibrium and at any time $\mathrm{t} ; \mathrm{K}_{2}=$ pseudo-second-order rate constant $(\mathrm{g} / \mathrm{\mu g} / \mathrm{min})$. The linear interpolation of the graph between $\mathrm{t} / \mathrm{q}_{\mathrm{t}}$ versus $t$ will give the values of $\mathrm{q}_{\mathrm{e}}$ (1/slope) and adsorption rate constant $\mathrm{K}_{2}$ (slope ${ }^{2}$ /intercept). From Fig. $8 \mathrm{~b}$, the linear plot was observed which indicates the validity of pseudo-secondorder kinetic model for all five initial As(V) concentrations. The values of pseudo-second-order rate constant $\left(\mathrm{K}_{2} \times 10^{-3}\right)$ were calculated as $1.813,1.892,1.647,1.841$ and 2.527 within the specified concentration range. The reaction rate was faster for $250 \mu \mathrm{g} / \mathrm{L}$ initial As(V) concentration, whereas

\begin{tabular}{|c|c|c|c|c|c|c|c|c|}
\hline \multirow{2}{*}{$\begin{array}{l}\text { Initial As }(\mathrm{V}) \\
\text { conc. }(\mu \mathrm{g} / \mathrm{L})\end{array}$} & \multicolumn{3}{|c|}{ Pseudo-first order } & \multicolumn{3}{|c|}{ Pseudo-second order } & \multicolumn{2}{|c|}{ Weber-Morris model } \\
\hline & $\begin{array}{l}\mathrm{K}_{1} \times 10^{-3} \\
\left(\mathrm{~min}^{-1}\right)\end{array}$ & $\begin{array}{l}\mathrm{q}_{\mathrm{e}} \\
(\mu \mathrm{g} / \mathrm{g})\end{array}$ & $\mathrm{R}^{2}$ & $\begin{array}{l}\mathrm{K}_{2} \times 10^{-3} \\
(\mathrm{~g} / \mu \mathrm{g} / \mathrm{min})\end{array}$ & $\begin{array}{l}\mathrm{q}_{\mathrm{e}} \\
(\mu \mathrm{g} / \mathrm{g})\end{array}$ & $\mathrm{R}^{2}$ & $\begin{array}{l}\mathrm{k}_{\mathrm{i}} \\
\left(\mu \mathrm{g} / \mathrm{g} / \min ^{0.5}\right)\end{array}$ & $\mathrm{R}^{2}$ \\
\hline 50 & 2.303 & 2.647 & 0.678 & 1.813 & 8.621 & 0.993 & 0.281 & 0.919 \\
\hline 100 & 4.606 & 3.908 & 0.825 & 1.892 & 16.394 & 0.997 & 0.359 & 0.928 \\
\hline 150 & 4.606 & 4.886 & 0.712 & 1.647 & 24.393 & 0.988 & 0.458 & 0.894 \\
\hline 200 & 4.606 & 4.753 & 0.714 & 1.841 & 32.251 & 0.999 & 0.459 & 0.897 \\
\hline 250 & 2.303 & 3.404 & 0.708 & 2.524 & 38.462 & 0.999 & 0.346 & 0.914 \\
\hline
\end{tabular}

Table 2: The kinetic model parameters for the sorption of As(V) on HBO1. 
a slower reaction rate was observed at intermediate initial As(V) concentration (50, 100, 150, $200 \mu \mathrm{g} / \mathrm{L})$. The lower values of $\mathrm{K}_{2}$ indicate fast adsorption process (Ayoob et al. 2008). The correlation coefficients of pseudo-second-order kinetics were having a high degree of correlation than the pseudo-first-order. Hence, the kinetic study indicates pseudosecond-order reaction in the sorption process of $\mathrm{As}(\mathrm{V})$ by HBO1.

Weber-Morris model: The linear form of the intraparticle diffusion model given by Weber-Morris (Weber Jr et al. $1963)$ is as follows in eq. (4):

$$
q=k_{\mathrm{i}} \sqrt{t}
$$

Where, $\mathrm{q}=$ Arsenic adsorbed $(\mu \mathrm{g} / \mathrm{g}) ; \mathrm{k}_{\mathrm{i}}=$ Rate constant; $\mathrm{t}=$ contact time $(\mathrm{min})$. The values of intraparticle diffusion rate constants $\mathrm{k}_{\mathrm{i}}$ could be determined from the slopes of the plots between $\sqrt{t}_{\mathrm{t}}(\sqrt{ } \mathrm{min})$ and $\mathrm{q}(\mu \mathrm{g} / \mathrm{g})$. From Fig. $8 \mathrm{c}$, the plots show poor linearity $\left(\mathrm{R}^{2}=0.894,0.897\right)$ at 150 and $200 \mu \mathrm{g} / \mathrm{L}$ arsenic concentrations and high linearity $\left(\mathrm{R}^{2}=0.919,0.928\right.$ and 0.914 ) at 50,100 and $250 \mu \mathrm{g} / \mathrm{L}$ arsenic concentrations. The intraparticle diffusion rate constants $\mathrm{k}_{\mathrm{i}}$ were found to be $0.281,0.359,0.458,0.459$ and $0.346 \mathrm{mg} / \mathrm{g} / \mathrm{min}^{0.5}$ for initial arsenic concentration of 50,100,150, 200 and $250 \mu \mathrm{g} / \mathrm{L}$ respectively. A linear representation of data elucidates the diffusion of the solute particle with the available pore site of adsorbent (Sujana \& Mohanty 2010). Further non zero intercepts represent the slow and complex diffusion process, which is not governed by a single mechanism (Gupta \& Bhattacharyya 2011).

Adsorption isotherm models: Adsorption isotherm models have been incorporated to calculate the maximum adsorption capacity of the adsorbent. At the equilibrium stage, there is an apparent distribution of a solute between the solid and liquid phases (Manna \& Ghosh 2007). Langmuir and Freundlich models are the most frequently used quantitative equations to describe present experimental adsorption data. Langmuir isotherm is based on the principle that each site on the surface of adsorbent is equally capable for adsorbing one molecule of adsorbate in a single monolayer thickness, whereas Freundlich isotherm could be applicable for heterogeneous surfaces of adsorbent with multilayer sorption (Milmile et al. 2011).

Langmuir isotherm: The Langmuir isotherms were chosen to determine the maximum adsorption capacity corresponding to the complete monolayer coverage on the hydrous bismuth oxide (HBO1). As given in eq. (5):

$$
\frac{1}{\mathrm{q}_{\mathrm{e}}}=\frac{1}{\mathrm{q}_{\mathrm{obC}}}+\frac{1}{\mathrm{q}_{\mathrm{o}}}
$$

Where, $\mathrm{C}_{\mathrm{e}}$ is the solute concentration at equilibrium $(\mu \mathrm{g} / \mathrm{L}) ; \mathrm{q}_{\mathrm{e}}$ is the equilibrium arsenic uptake $(\mu \mathrm{g} / \mathrm{g}) ; \mathrm{q}_{\mathrm{o}}$ and bare Langmuir constants related to maximum monolayer capacity $(\mu \mathrm{g} / \mathrm{g})$ and energy of adsorption $(\mathrm{L} / \mu \mathrm{g})$. Value of $\mathrm{q}_{\mathrm{o}}$

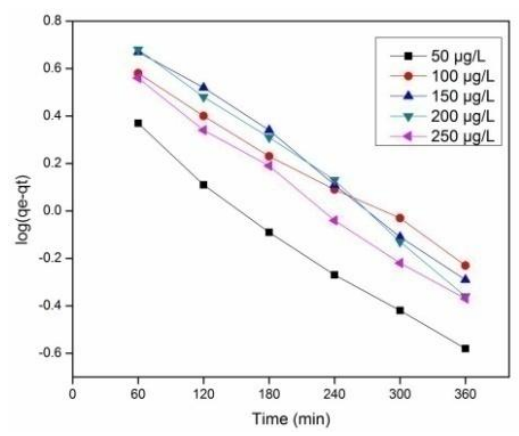

(a)

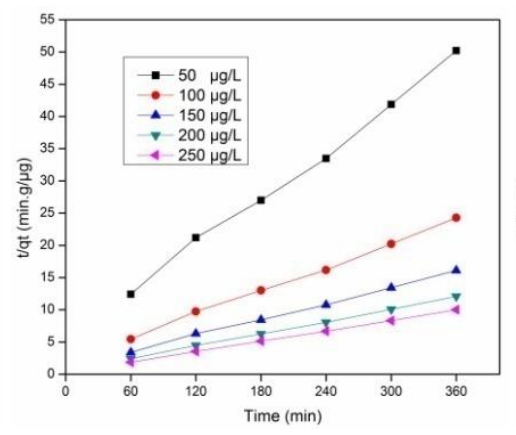

(b)

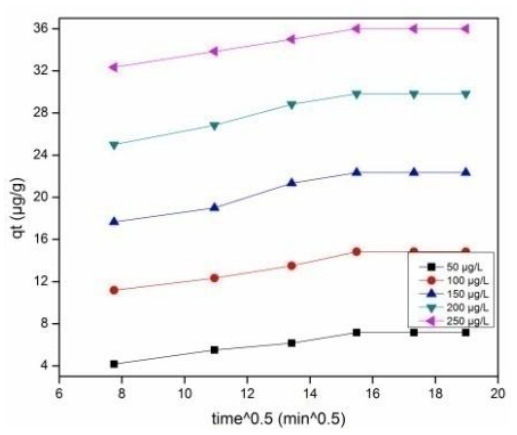

(c)

Fig. 8: Kinetic plot of As(V) on HBO1 (a) Pseudo-first order (b) Pseudo-second order (c) Weber-Morris kinetic.

\begin{tabular}{|c|c|c|c|c|c|c|c|c|c|c|c|c|}
\hline \multirow[t]{2}{*}{$\begin{array}{l}\text { Temperature } \\
(\mathrm{K})\end{array}$} & \multicolumn{3}{|c|}{$\begin{array}{l}\text { Langmuir } \\
\text { parameters }\end{array}$} & \multicolumn{3}{|c|}{ Freundlich parameters } & \multicolumn{4}{|c|}{$\begin{array}{l}\text { Dubinin-Radushkevich } \\
\text { parameters }\end{array}$} & \multicolumn{2}{|c|}{$\begin{array}{l}\text { Thermodynamic } \\
\text { parameters }\end{array}$} \\
\hline & $\begin{array}{l}\mathrm{q}_{\mathrm{o}} \\
(\mu \mathrm{g} / \mathrm{g})\end{array}$ & $\begin{array}{l}\mathrm{b} \\
(\mathrm{L} / \mu \mathrm{g})\end{array}$ & $\mathrm{R}^{2}$ & $\mathrm{~K}_{\mathrm{f}}$ & $\mathrm{n}$ & $\mathrm{R}^{2}$ & $\begin{array}{l}\mathrm{q}_{\mathrm{a}} \\
(\mu \mathrm{g} / \mathrm{g})\end{array}$ & $\begin{array}{l}\mathrm{E} \\
(\mathrm{kJ} / \text { mole })\end{array}$ & $\mathrm{R}^{2}$ & $\begin{array}{l}\mathrm{G}^{\mathrm{o}} \\
(\mathrm{kJ} / \mathrm{mol})\end{array}$ & $\begin{array}{l}\mathrm{H}^{\mathrm{o}} \\
(\mathrm{kJ} / \mathrm{mol})\end{array}$ & $\begin{array}{l}\mathrm{S}^{\mathrm{o}} \\
(\mathrm{J} / \mathrm{mol})\end{array}$ \\
\hline 298 & 83.33 & 0.011 & 0.96 & 1.14 & 0.97 & 0.94 & 4.073 & 5.42 & 0.96 & -0.61 & 18.84 & 64.97 \\
\hline 308 & 100 & 0.012 & 0.95 & 1.17 & 0.98 & 0.95 & 4.072 & 8.63 & 0.97 & -0.95 & - & - \\
\hline 318 & 125 & 0.019 & 0.97 & 1.24 & 0.99 & 0.96 & 4.067 & 6.20 & 0.96 & -1.92 & - & - \\
\hline
\end{tabular}

Table 3: Isotherm parameters with thermodynamics for the sorption of Arsenic(v) on HBO1. 
and $b$ are calculated from the slope and intercept $1 / \mathrm{C}_{\mathrm{e}}$ and $1 / \mathrm{q}_{\mathrm{e}}$ (Fig. 9a) and is given in Table 3 . $\mathrm{q}_{\mathrm{o}}$ was found to be 83.33 , 100 and $125 \mu \mathrm{g} / \mathrm{g}$ at $298 \mathrm{~K}, 308 \mathrm{~K}$ and $318 \mathrm{~K}$ respectively. The Langmuir isotherm plot at different temperatures gives higher values of correlation coefficients $\left(R^{2}\right)$. The highest value of ' $\mathrm{q}_{\mathrm{o}}$ ' was obtained as $125 \mu \mathrm{g} / \mathrm{g}$ at the temperature of $318 \mathrm{~K}$ (Table 4). A high value of $\mathrm{q}_{\mathrm{o}}$ at elevated temperature indicates the enhancement in arsenic sorption potential of HBO1 (Singh et al. 2015).

Freundlich isotherm: The expression of Freundlich equation is given below (eq. 6):

$$
\log \mathrm{q}_{\mathrm{e}}=\log \mathrm{K}_{\mathbf{f}}+\frac{1}{\mathrm{n}} \log \mathrm{C}_{\mathrm{e}}
$$

Where, $\mathrm{q}_{\mathrm{e}}=$ Equilibrium arsenic uptake $(\mu \mathrm{g} / \mathrm{g}) ; \mathrm{C}_{\mathrm{e}}=$ Solute concentration at equilibrium $(\mu \mathrm{g} / \mathrm{L}) ; \mathrm{K}_{\mathrm{f}}$ and $\mathrm{n}$ are the Freundlich constants corresponding to adsorption capacity and adsorption intensity, respectively. The value of " $n$ " could be correlated with the favourable and unfavourable condition of adsorption. Hence " $n$ " represents the bonding between adsorbate and adsorbent. Beneficial or favourable adsorption could be read if the value of $n(>0)$ lies in between 1 and 10 (Ho \& McKay 2011).

Fig. 9b shows the linearized plot of Freundlich isotherm for As (V) adsorption on HBO1. Regression coefficients $\left(\mathrm{R}^{2}\right)$ was found higher $(>0.95)$ at all temperature. Based on the value of " $n$ " adsorption seems to be 'beneficial' at elevated temperature of $318 \mathrm{~K}$. Freundlich parameter, $\mathrm{K}_{\mathrm{f}}$ is found as $1.14,1.16$ and 1.24 at $298 \mathrm{~K}, 308 \mathrm{~K}$ and $318 \mathrm{~K}$ (Table 3 ). Increased value of $\mathrm{K}_{\mathrm{f}}$ at higher temperature indicates the favourable condition of adsorption (Sharma et al. 2009). The adsorption patterns of $\mathrm{HBO} 1$ can be described well by the Langmuir isotherm as it has high correlation coefficient values than Freundlich with a maximum adsorption capacity of $125 \mu \mathrm{g} / \mathrm{g}$ at a temperature of $318 \mathrm{~K}$. The suitability of
Langmuir isotherm leads to the conclusion that the homogenous nature of sorption site dominated over the surface of adsorbent and single layer arsenic sorption took place over the surface of HBO1.

Dubinin-Radushkevich (D-R) isotherm: DubininRadushkevich isotherm has also been included in the present study to make a clear understanding between adsorption and ion exchange. The equation of $\mathrm{D}-\mathrm{R}$ isotherm is given below in eq. (7):

$$
\ln q_{\mathrm{e}}=\ln q_{\mathrm{a}}-K^{\circ} \varepsilon^{2}
$$

Where $\mathrm{q}_{\mathrm{e}}=$ Arsenic adsorbed at equilibrium $(\mu \mathrm{g} / \mathrm{g}), \mathrm{q}_{\mathrm{a}}$ $=$ Theoretical adsorption capacity, $K^{\circ}=$ Adsorption energy constant.

$\mathrm{E}=$ Polanyi potential is given as follows in eq. (8) (Islam et al. 2010):

$$
\varepsilon=R T \ln \left(1+\frac{1}{C_{\mathrm{e}}}\right)
$$

Where, $\mathrm{R}$ is the universal gas constant $(\mathrm{kJ} / \mathrm{mol} \mathrm{K})$; $\mathrm{T}$ is the temperature(K). The high values of $R^{2}$ at $298 \mathrm{~K}, 308 \mathrm{~K}$ and $318 \mathrm{~K}$ temperatures show a good correlation of data with D-R isotherm. The values of $K^{\circ}\left(\mathrm{mol}^{2} / \mathrm{J}^{2}\right)$ were calculated from Fig.8c and found as 0.017, 0.0067 and $0.013 \mathrm{~mol}^{2} \mathrm{~kJ}^{-2}$ respectively at $298 \mathrm{~K}, 308 \mathrm{~K}$ and $318 \mathrm{~K}$.

The adsorption energy (E) was calculated using the following relation given in eq (9) (Sharma et al. 2009):

$$
E=1 / \sqrt{ }\left(2 K^{\circ}\right)
$$

Process of adsorption can be easily classified into chemical, physical and ion exchange based on the adsorption energy (E). Physical adsorption will prevail if adsorption energy is below $8 \mathrm{~kJ} / \mathrm{mol}$, if it is between $8-16 \mathrm{~kJ} / \mathrm{mol}$ ion exchange will take place, while if it is over $16 \mathrm{~kJ} / \mathrm{mol}$ then

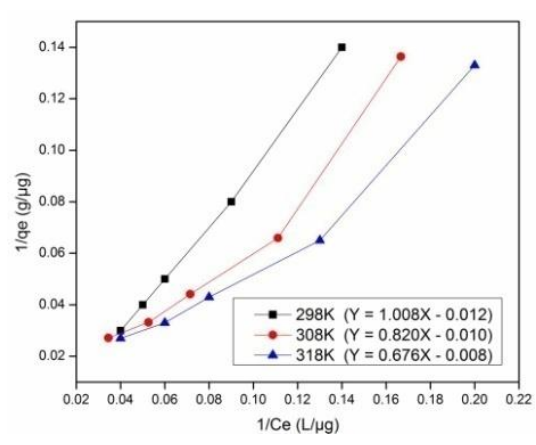

(a)

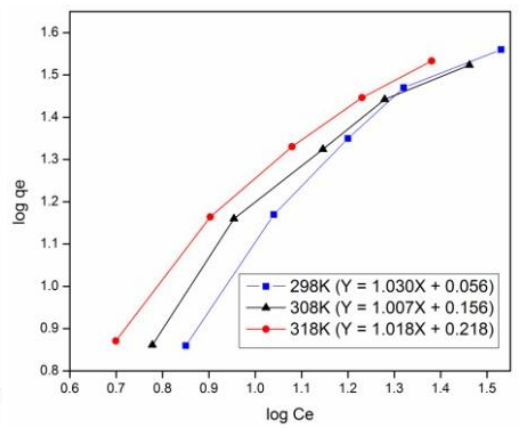

(b)

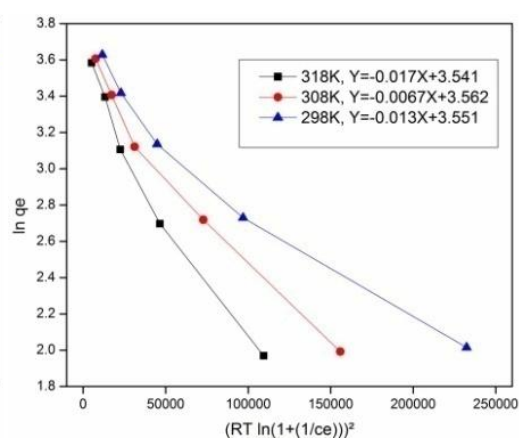

(c)

Fig. 9: Isotherm plot of As(V) sorption by HBO1 (a) Langmuir isotherm (b) Freundlich isotherm (c) DR isotherm. 
Table 4: Arsenic(v) removal from water using hydrous metal oxides (HMOs)

\begin{tabular}{|c|c|c|c|c|c|}
\hline Adsorbent & $\begin{array}{l}\text { Optimum } \\
\text { Temperature }\left({ }^{\circ} \mathrm{C}\right)\end{array}$ & $\begin{array}{l}\text { Removal } \\
\text { efficiency/potential (mg/g) }\end{array}$ & Optimum pH & $\begin{array}{l}\text { Contact } \\
\text { Time }(\mathrm{h})\end{array}$ & References \\
\hline Granular titanium dioxide & 25 & 41.4 & 7.3 & 2 & Bang et al.(2005) \\
\hline Manganese dioxide & - & 53 & $4.3-3.9$ & 2 & Lenoble et al.(2004) \\
\hline Hydrous stannic oxide & 27 & 4.3 & $6.5-8.5$ & 4 & Manna and Ghosh (2007) \\
\hline Hydrous ferric oxide & 40 & $<100 \%$ & $2-12$ & 4 & Jang and Dempsey (2008) \\
\hline Cupric oxide & $21-25$ & 22.6 & $6-10$ & 0.5 & Martinson and Reddy (2009) \\
\hline Magnetite $\left(\mathrm{Fe}_{3} \mathrm{O}_{4}\right)$ & $20-30$ & 0.485 & 8 & 1 & Shipley et al.(2010) \\
\hline Hydrous titanium dioxide & $20-23$ & $22.0-33.4$ & $4-6$ & 4 & Pirila et al. (2011) \\
\hline Hydrous zirconium oxide & 25 & 3.6 & 7 & 4 & Hang et al. (2011) \\
\hline Iron oxide nano materials & 25 & 671.1 & $6-9$ & 1 & Luther et al.(2012) \\
\hline Hydrous cerium oxide & 25 & 107 & 7 & 24 & Li et al. (2012) \\
\hline Zirconium oxide-coated marine & 35 & 0.270 & 7 & 1.25 & Khan et al. (2013) \\
\hline Manganese oxide & 25 & $71.2 \%$ & 6 & 24 & Hou et al. (2017) \\
\hline Hydrous bismuth oxide & 25 & $0.013-0.019$ & $6.6-8.4$ & 3 & Present study \\
\hline
\end{tabular}

mechanism will be known as chemical adsorption (Inglezakis $\&$ Zorpas 2012). The values of E using Eq. (10) were found as $5.42,8.63$ and $6.20 \mathrm{~kJ} / \mathrm{mol}$ respectively at the studied temperatures. Hence, the adsorption of arsenic on HBO1 is governed by physical adsorption process (Kanjilal et al. 2017). Srivastav et al. (2013) research supported the findings of adsorption energy highlighting the probability of physical adsorption.

Among all adsorption isotherm models, Langmuir isotherm as well as Freundlich fits well at all selected temperatures for arsenic sorption by HBO1. Based on the calculation of mean adsorption energy (E) from D-R isotherm, the mechanism of arsenic removal by HBO1 fall under the category of the physical adsorption process.

Many adsorbents have been tested for As(V) sorption from aqueous solution and listed in Table 4. The adsorption capacity of hydrous cerium oxide is reported as $107 \mathrm{mg} / \mathrm{g}(\mathrm{Li}$ et al. 2012). While cupric oxide demonstrated the adsorption capacity of $22.6 \mathrm{mg} / \mathrm{g}$ (Martinson \& Reddy 2009), hydrous titanium dioxide showed the capacity of $22.0-33.4 \mathrm{mg} / \mathrm{g}$ (Pirila et al. 2011). Iron oxide nanomaterial and zirconium oxide-coated marine came with an adsorption capacity of $671.1 \mathrm{mg} / \mathrm{g}$ (Luther et al. 2012) and $0.270 \mathrm{mg} / \mathrm{g}$ (Khan et al. 2013). In the present study, increasing value of arsenic sorption potentials was demonstrated by hydrous bismuth oxide (HBO1) with increasing temperature of 298 to $318 \mathrm{~K}$ and maximum of $19.6 \mathrm{mg} / \mathrm{g}$ adsorption capacity noted down at temperature of $318 \mathrm{~K}$.

\section{Thermodynamics Studies}

Thermodynamic parameters like Gibbs free energy $\left(G^{\circ}\right)$, enthalpy $\left(\mathrm{H}^{\mathrm{O}}\right)$ and entropy $\left(\mathrm{S}^{\mathrm{o}}\right)$ were determined for arsenic adsorption on HBO1 from eqs. (6) and (7) (Banerjee et al. 2014).

$$
\begin{gathered}
\ln \mathrm{M}=\frac{\Delta \mathrm{S}^{\circ}}{\mathrm{R}}-\Delta \mathrm{H}^{\circ} / \mathrm{RT} \\
\Delta \mathrm{G}=-\mathrm{RT} \ln \mathrm{M}
\end{gathered}
$$

Where, $\mathrm{R}=$ Gas constant $(8.314 \mathrm{~J} / \mathrm{mol} \mathrm{K}), \mathrm{T}=$ Absolute temperature (Kelvin), $\mathrm{M}=$ Standard thermodynamic equilibrium constant $(\mathrm{L} / \mathrm{g})$.

Values of ' $M$ ' is obtained by plotting $\operatorname{In}\left(\mathrm{q}_{e} / \mathrm{C}_{\mathrm{e}}\right)$ versus $\mathrm{q}_{\mathrm{e}}$ and extrapolating to zero $\mathrm{q}_{\mathrm{e}}$ as the methods reported by Khan $\&$ Singh (1987). The intersection with the vertical axis gives the value of ' $M$ '. Further, the value of $\Delta H^{\circ}$ and $\Delta S^{\circ}$ were calculated from the slope and intercept from the graph between $\operatorname{lnM}$ and 1/T (Liu and Liu 2008) as summarized in Table 4.

Spontaneous nature of the $\mathrm{As}(\mathrm{V})$ sorption by $\mathrm{HBO} 1$ is confirmed as the negative value of $\Delta \mathrm{G}^{\mathrm{o}}$ was found at all temperatures. The more spontaneous behaviour of adsorption at higher temperature could be observed with a high value of $\Delta \mathrm{G}^{\mathrm{o}}$ with increasing temperatures (Raji \& Anirudhan 1998). The positive value of $\Delta \mathrm{H}^{\mathrm{o}}$ suggests the endothermic nature of the sorption process (Tangkawanit et al. 2005). A positive value of $\Delta \mathrm{H}^{\mathrm{o}}$ with magnitude $13.96 \mathrm{~kJ} / \mathrm{mol}$ was also reported by Singh et al. (2015) during nitrate adsorption on hydrous bismuth oxide. No remarkable change in entropy $\left(\Delta S^{\circ}\right)$ has been observed due to sorption of arsenic by HBO1. Similar results have been documented by Liu \& Liu (2008) with a low value of entropy in sorption thermodynamics and further Chaudhry et al. (2017) verified with a value of $0.0144 \mathrm{~kJ} /$ $\mathrm{mol} / \mathrm{K}$ as entropy change in his arsenic removal experiment using zirconium oxide-coated sand. 


\section{CONCLUSION}

The present study elucidates hydrous bismuth oxide (HBO1) has augmented removal efficiency towards As(V) among arsenic species from aqueous solution. As(V) removal efficiency of $94 \%$ and As(V) sorption potential of 13.1-19.6 $\mathrm{mg} / \mathrm{g}$ has been found in batch and fixed-bed column study respectively. Elution of chloride can be better correlated with ion exchange phenomenon but adsorption energy calculation indicates that the process is governed by physical adsorption. Hence a mixed mechanism of ion exchange and physical adsorption can be concluded in As(V) sorption by HBO1. $\mathrm{XRD}$ analyses reveal the relevant peaks corresponds to $\mathrm{Bi}_{12} \mathrm{O}_{17} \mathrm{C}_{12}$ (ID: 370702) indicating the presence of chloride inside it. Thus, results attribute that adsorbent shows a high efficiency of arsenic sorption and can be used as an efficient scavenger of arsenic from aqueous solution.

The affinity of hydrous bismuth oxide towards arsenic in addition to nitrate and fluoride (reported in the literature) makes it a unique adsorbent. Hence, hydrous bismuth oxide could be a better alternative for the simultaneous removal of all three major water toxins such as nitrate, fluoride and arsenic from aqueous solution. This aspect needs to be explored in future studies with close monitoring.

\section{ACKNOWLEDGEMENTS}

All the necessary facilities for this work have been provided by the Indian Institute of Technology (Banaras Hindu University), India. The author avails the opportunity to express sincere thanks to anonymous reviewers for their valuable comments and suggestion.

\section{REFERENCES}

Anđelković, I., Amaizah, N.R.R., Marković, S.B., Stanković, D., Marković, M., Kuzmanović, D. and Roglić, G. 2017. Investigation of mechanism and critical parameters for removal of arsenic from water using $\mathrm{Zr}-\mathrm{TiO}_{2}$ Composite. Env. Tech., 38: 2233-2240.

Ayoob, S., Gupta, A.K. and Bhat, V.T. 2008. A conceptual overview on sustainable technologies for defluoridation of drinking water and removal mechanisms. Critical Rev. Environ. Sci. Tech., 38(6): 401-470.

Banerjee, S., Sharma, G.C., Chattopadhyaya, M.C. and Sharma, Y.C. 2014. Kinetic and equilibrium modeling for the adsorptive removal of methylene blue from aqueous solutions on of activated fly ash (AFSH). J. Environ. Chem. Eng., 2: 1870-1880.

Bang, S., Patel, M., Lippincott, L. and Meng, X. 2005. Removal of arsenic from groundwater by granular titanium dioxide adsorbent. Chemosphere, 60: 389-397.

Basu, T. and Ghosh, U.C. 2011. Influence of groundwater occurring ions on the kinetics of As (III) adsorption reaction with synthetic nanostructured $\mathrm{Fe}(\mathrm{III})-\mathrm{Cr}(\mathrm{III})$ mixed oxide. Desalination, 266: 25-32.

Basu, T., Gupta, K. and Ghosh, U.C. 2012. Performances of As(V) adsorption of calcined $\left(250^{\circ} \mathrm{C}\right)$ synthetic iron(III)- aluminum(III) mixed oxide in the presence of some groundwater occurring ions. Chem. Eng. J., 183: 303-314.
Bhatnagar, A. and Sillanpaa, M. 2011. A review of emerging adsorbents for nitrate removal from water. Chem. Eng. J., 168: 493-504.

Chaudhry, S.A., Khan, T.A. and Ali, I. 2017. Zirconium oxide-coated sand based batch and column adsorptive removal of arsenic from water: Isotherm, kinetic and thermodynamic studies. Egypt. J. Petrol., 26: 553-563.

Clesceri, L.S., Greenberg, A.E. and Eaton, A.D. 2005. Standard Methods for the Examination of Water Wastewater, American Public Health Association, 20th ed., Washington, DC.

Deng, M., Wu, X., Zhu, A., Zhang, Q. and Liu, Q. 2019. Well-dispersed $\mathrm{TiO}_{2}$ nanoparticles anchored on $\mathrm{Fe}_{3} \mathrm{O}_{4}$ magnetic nanosheets for efficient arsenic removal. J. Environ. Manage., 237: 63-74.

Doušova, B., Machovic, V., Koloušek, D., Kovanda, F. and Dornicak, V. 2003. Sorption of As (V) species from aqueous systems. Water Air Soil Pollution, 149: 251-267.

Fritsche, U. 1993. Removal of nitrate and other anions from water by yellow bismuth hydroxide. J. Environ. Sci. Health (A) Tox. Hazard. Subst. Environ. Eng., 28: 1903-1913.

Gu, B., Ku, Y.K. and Jardine, P.M. 2004. Sorption and binary exchange of nitrate, sulfate, and uranium on an anion exchange resin. Environ. Sci. Technol., 38(11): 3184-3188.

Gupta, K. and Ghosh, U.C. 2009. Arsenic removal using hydrous nanostructure iron (III)-titanium(IV) binary mixed oxide from aqueous solution. J. Hazard. Mater., 161: 884-892.

Gupta, S.S. and Bhattacharyya, K.G. 2011. Kinetics of adsorption of metal ions on inorganic materials: A review. Adv. Colloid Interface. Sci., 162: 39-58.

Hang, C., Li, Q., Gao, S. and Shang, J.K. 2011. As(III) and As(V) Adsorption by hydrous zirconium oxide nanoparticles synthesized by a hydrothermal process followed with heat treatment. Ind. Eng. Chem. Res., 51: 353-361.

Ho, Y.S. and McKay, G. 1999. Pseudo-second order model for sorption processes. Process Biochem., 34: 451-465.

Hou, J., Luo, J., Song, S., Li, Y. and Li, Q. 2017. The remarkable effect of the coexisting arsenite and arsenate species ratios on arsenic removal by manganese oxide. Chem. Eng. J., 315: 159-166.

Iesan, C.M., Capat, C., Ruta, F. and Udrea, I. 2008. Evaluation of a novel hybrid Inorganic/organic polymer type material in the arsenic removal process from drinking water. Water Res., 42: 4327-4333.

Inchaurrondo, N., Di Luca, C., Mori, F., Pintar, A., Zerjav, G., Valiente, M. and Palet, C. 2019. Synthesis and adsorption behavior of mesoporous alumina and Fe-doped alumina for the removal of dominant arsenic species in contaminated waters. J. Environ. Chem. Eng., 7(1): 102901.

Inglezakis, V.J. and Zorpas, A.A. 2012. Heat of adsorption, adsorption energy and activation energy in adsorption and ion exchange system. Desalin. Water Treat., 39: 149-157.

Islam, M., Mishra, P.C. and Patel, R.K. 2010. Physicochemical characterization of hydroxy-apatite and its application towards removal of nitrate from water. J. Environ. Manage., 91: 1883-1891.

Jang, J.H. and Dempsey, B.A. 2008. Co-adsorption of arsenic (III) and arsenic (V) onto hydrous ferric oxide:effects on abiotic oxidation of arsenic (III), extraction efficiency and model accuracy. Environ. Sci. Technol., 42: 2893-2898.

Kanjilal, T., Bhattacharjee, C. and Datta, S. 2017. Assessing treatment of lead $(\mathrm{Pb}$ II) from industrial wastewater on dried bulbs of water hyacinth:adsorption capacity, isotherm and kinetic study. Int. J. Environ. Tech. Mgt., 20: 101-127.

Khan, A.A. and Singh, R.P.1987. Adsorption thermodynamics of carbofuran on $\mathrm{Sn}$ (IV) arsenosilicate in $\mathrm{H}^{+}, \mathrm{Na}^{+}$and $\mathrm{Ca}^{2+}$ Forms. Colloids and Surf., 24: 33-42.

Khan, B.I., Solo-Gabriele, H.M., Dubey, B.K., Townsend, T.G. and Cai, Y. 2004. Arsenic speciation of solvent-extracted leachate from new and weathered CCA-treated wood. Environ. Sci. Techno., 138(17): $4527-4534$. 
Khan, T.A., Chaudhry, S.A. and Ali, I. 2013. Thermodynamic and kinetic studies of $\mathrm{As}(\mathrm{V})$ removal from water by zirconium oxide-coated marine sand. Environ. Sci. Pollut. Res., 20: 5425-5440.

Kong, S., Wang, Y., Zhan, H., Yuan, S., Yu, M. and Liu, M. 2014. Adsorption/oxidation of arsenic in groundwater by nanoscale Fe-Mn binary oxides loaded on zeolite. Water Environ. Res., 86(2): 47-155.

Lagergren, S. 1898. About the theory of so-called adsorption of soluble substances. K. Sven. Vetensk. Akad. Handl., 24: 1-39.

Lenoble, V., Chabroullet, C., Al Shukry, R., Serpaud, B., Deluchat, V. and Bollinger, J.C. 2004. Dynamic arsenic removal on a $\mathrm{MnO}_{2}$-loaded resin. J. Colloid Interface Sci., 280: 62-67.

Li, R., Li, Q., Gao, S. and Shang, J.K. 2012. Exceptional arsenic adsorption performance of hydrous cerium oxide nanoparticles: Part A. Adsorption capacity and Mechanism. Chem. Eng. J., 185: 127-135.

Li, Y., Liu, Z., Li, Q., Zhao, Z., Liu, Z. and Zeng, L. 2011. Removal of arsenic from Waelz zinc oxide using a mixed $\mathrm{NaOH}-\mathrm{Na}_{2} \mathrm{~S}$ leach. Hydrometallurgy, 108: 165-170.

Li, Z., Deng, S., Yu, G., Huang, J. and Lim, V.C. 2010. As(V) and As(III) removal from water by a $\mathrm{Ce}-\mathrm{Ti}$ oxide adsorbent: Behavior and mechanism. Chem. Eng. J., 161: 106-113.

Liu, Y. and Liu, Y.J. 2008. Biosorption isotherms, kinetics and thermodynamics. Sep. Purif. Technol., 61: 229-242.

Luther, S., Borgfeld, N., Kim, J. and Parsons, J.G. 2012. Removal of arsenic from aqueous solution: A study of the effects of $\mathrm{pH}$ and interfering ions using iron oxide nanomaterials. Microchem. J., 101: 30-36.

Manna, B. and Ghosh, U.C. 2007. Adsorption of arsenic from aqueous solution on synthetic hydrous stannic oxide. J. Hazard Mater., 144: 522-531.

Martinson, C.A. and Reddy, K.J. 2009. Adsorption of arsenic(III) and arsenic(V) by cupric oxide nanoparticles. J. Colloid Interface Sci., 336: 406-411.

Milmile, S.N., Pande, J.V., Karmakar, S., Bansiwal, A., Chakrabarti, T. and Biniwale, R.B. 2011. Equilibrium isotherm and kinetic modeling of the adsorption of nitrates by anion exchange Indion NSSR resin. Desalination, 276: 38-44.

Mudhoo, A., Sharma, S.K, Garg, V.K. and Tseng, C.H. 2011. Arsenic: an overview of applications, health, and environmental concerns and removal processes. Crit. Rev. Environ. Sci. Technol., 41: 435-519.

Nath, B., Sahu, S.J., Jana, J., Goswami, A.M., Roy, S., Sarkar, M.J. and Chatterjee, D. 2008. Hydrochemistry of arsenic-enriched aquifer from rural west bengal, india: a study of the arsenic exposure and mitigation option. Water Air Soil Pollution, 190: 95-113.

Ngai, T.K.K. 2002. Arsenic speciation and evaluation of an adsorption media in Rupandehi and Nawalparasi Districts of Nepal. Dissertation, Massachusetts Institute of Technology, USA.

Ngai, T.K.K., Murcott, S., Shrestha, R.R., Dangol, B. and Maharjan, M. 2006. Development and dissemination of Kanchan arsenic filter in rural Nepal. Water Sci. Technol: Water Supply, 6(3): 137-146.

PAN alyticalX'Pert High Score Plus Software: V 3.0, 2009.

Park, J.Y., Byun, H.J., Choi, W.H. and Kang, W.H. 2008. Cement paste column for simultaneous removal of fluoride, phosphate, and nitrate in acidic wastewater. Chemosphere, 70: 1429-1437.

Park, Y.J., Yang, J., Choi, H.J. and Lee, S.M. 2012. Removal of arsenic from aqueous solution using hybrid metal oxide. Environ. Eng. Res., S1: S15-S19.

Pirila, M., Martikainen, M., Ainassaari, K., Kuokkanen, T. and Keiski, R.L. 2011. Removal of aqueous As(III) and As(V) by hydrous titanium dioxide. J. Colloid Interface Sci. 353: 257-262.

Puente-Urbina, A. and Montero-Campos, V. 2017. Porous materials modified with $\mathrm{Fe}_{3} \mathrm{O}_{4}$ nanoparticles for arsenic removal in drinking water. Water Air Soil Pollution, 228: 374.

Raji, C. and Anirudhan, T.S. 1998. Batch Cr (VI) removal by polyacrylamidegrafted sawdust: Kinetics and thermodynamics. Water Res., 32(12): $3772-3780$
Ramli, I., Tze, C.M. and Hin, T.Y. 2007. Effect of sodium hydroxide concentration on the physic chemical characteristicof $\alpha-\mathrm{Bi}_{2} \mathrm{O}_{3}$ nanocrystals. J. Solid State Sci. Technol., 15: 30-42.

Ranjan, M., Singh, P.K. and Srivastav, A.L. 2019. A review of bismuthbased sorptive materials for the removal of major contaminants from drinking water. Environ. Sci. Pollut. Res. Int., https://doi.org/10.1007/ s11356-019-05359-9.

Ranjan, M., Singh, P.K., Srivastav, A.L. and Kumar, V. 2019. Adsorptive properties of cation added hydrous bismuth oxide on nitrate sorption. J. Water Chem. Tech., 41(5): 283-291.

Ranjan, M., Srivastav, A.L. and Shaktibala 2015. Effects of addition of cationic ligands in hydrous bismuth oxide on removal of fluoride from aqueous solutions. Curr. Sci., 108: 1673-1682.

Ren, Z., Zhang, G. and Paul, C.J. 2011. Adsorptive removal of arsenic from water by an iron-zirconium binary oxide adsorbent. J. Coll. Int. Sci., 358: 230-237.

Ruixia, L., Jinlong, G. and Hongxiao, T. 2002. Adsorption of fluoride, phosphate, and arsenate ions on a new type of ion exchange fiber. J. Coll. Int. Sci., 248: 268-274.

Sarkar, A. and Paul, B. 2016. The global menace of arsenic and its conventional remediation - A critical review. Chemosphere, 158: 37-49.

Sharma, Y.C., Uma and Upadhyay, S.N. 2009. Removal of a cationic dye from wastewater by adsorption on activated carbon developed from coconut coir. Energy Fuels, 23: 2983-2988.

Shipley, H.J., Yean, S., Kan, A.T. and Tomson, M.B. 2010. A sorption kinetics model for arsenic adsorption to magnetite nanoparticles. Env. Sci. \& Poll. Res., 17: 1053-1062.

Singh, P.K. 1999. Nitrate removal from water by bismuth based media. $\mathrm{PhD}$ Dissertation, Indian Institute of Technology, Kanpur.

Singh, P.K., Banerjee, S., Srivastava, A.L. and Sharma, Y.C. 2015. Kinetic and equilibrium modeling for removal of nitrate from aqueous solutions and drinking water by a potential adsorbent, hydrous bismuth oxide. RSC Adv., 5: 35365-35376.

Singh, P.K., Srivastav, A.L., Ghosh, D.K. and Chandra, Y.C. 2012. Preparation and properties of hydrous bismuth oxides for nitrate removal from aqueous solutions. Desalin. Water Treat., 40: 144-152.

Sinha, S., Amy, G., Yoon, Y. and Her, N. 2011. Arsenic removal from water using various adsorbents: magnetic ion exchange resins, hydrous ion oxide particles, granular ferric hydroxide, activated alumina, sulfur modified iron, and iron oxide-coated microsand. Environ. Eng. Res., 16(3): 165-173.

Song, H.O., Zhou, Y., Li, A.M. and Mueller, S. 2012. Selective removal of nitrate by using a novel macroporous acrylic anion exchange resin. Chin. Chem. Lett., 23: 603-606.

Srivastav, A. L. and Ranjan, M. (ed.) 2020. Inorganic water pollutants. Inorganic pollutants in water. Elsevier Publications. pp. 1-10.

Srivastav, A.L., Singh, P.K. and Sharma, Y.C. 2015. Synthesis of a novel adsorbent, hydrous bismuth oxide ( $\mathrm{HBO} 2$ ) for the removal of fluoride from aqueous solutions. Desalin. Water Treat., 55: 604-614.

Srivastav, A.L., Singh, P.K., Srivastava, V. and Sharma, Y.C. 2013. Application of a new adsorbent for fluoride removal from aqueous solutions. J. Hazard Mat., 263: 342-352.

Srivastav, A.L., Singh, P.K., Weng, C.H. and Sharma, Y.C. 2014. Novel adsorbent hydrous bismuth oxide for the removal of nitrate from aqueous solutions. J. Hazard Toxic Radioact. Waste, 04014028:1-8.

Sujana, M.G. and Mohanty, S. 2010. Characterization and fluoride uptake studies of nano-scale iron oxide-hydroxide synthesized by microemulsion method. Int. J. Eng. Sci. Technol., 2: 1-12.

Swain, S.K., Mishra, S., Patnaik, T., Patel, R.K., Jha, U. and Dey, R.K. 2012. Fluoride removal performance of a new hybrid sorbent of $\mathrm{Zr}(\mathrm{IV})-$ ethylenediamine. Chem. Eng. J., 184: 72-81.

Tangkawanit, S., Rangsriwatananon, K. and Dyer, A. 2005. Ion exchange of $\mathrm{Cu}^{2+}, \mathrm{Ni}^{2+}, \mathrm{Pb}^{2+}$ and $\mathrm{Zn}^{2+}$ in analcime(ANA) synthesized from Thai perlite. Microporous and Mesoporous Mater, 79: 171-175. 
Ustun, G.E., Solmaz, S.K.A. and Birgul, A. 2007. Regeneration of industrial district wastewater using a combination of Fenton process and ion exchange-A case study. Resour. Conserv. Recyc., 152: 425-440.

Vaclavikova, M., Gallios, G.P., Hredzak, S. and Jakabsky, S. 2008. Removal of arsenic from water streams: An overview of available techniques. Clean Technol. Environ., 10: 89-95.

Wagle, D. and Shipley, H.J. 2016. Adsorption of arsenic (V) to titanium dioxide nanoparticles: effect of particle size, solid concentration, and other metals. Environ. Eng. Sci., 33(5): 299-305.

Weber Jr, W.J. and Morris, J.C. 1963. Kinetics of adsorption on carbon from solution. J. Sanit. Eng. Div., 89: 31-59.

Wu, K., Zhang, J., Chang, B., Liu, T., Zhang, F., Jin, P., Wang, W. and Wang, X. 2017. Removal of arsenic (III, V) by agranular Mn-oxide-doped Al oxide adsorbent: Surface characterization and performance. Env. Sci. \& Poll. Res., 24: 18505-18519.

Yao, Y., Gao, B., Inyang, M., Zimmerman, A.R., Cao, X., Pullammanappalli,
I.P. and Yang, L. 2011. Removal of phosphate from aqueous solution by biochar derived from anaerobically digested sugar beet tailings. J. Hazard Mater., 190: 501-507.

Zhang, G., Ren, Z., Zhang, X. and Chen, J. 2013. Nanostructured iron(III)copper(II) binary oxide: A novel adsorbent for enhanced arsenic removal from aqueous solutions. Water Res., 47: 4022-4031.

Zhang, W., Liu, C., Wang, L., Zheng, T, Ren, G., Li, J., Ma, J., Zhang, G., Song, H., Zhang, Z. and Li, Z. 2018. A novel nanostructured Fe-Ti-Mn composite oxide for highly efficient arsenic removal: Preparation and performance evaluation. Colloids Surf. (A) Physicochem. Eng. Asp., https://doi.org/10.1016/j.colsurfa.2018.10.077.

Zhou, Q., Teng, Y. and Liu,Y. 2017. A study on soil-environmental quality criteria and standards of arsenic. Appl. Geochem., 77: 158-166.

Zhu, N., Yan, T., Qiao, J. and Cao, H. 2016. Adsorption of arsenic, phosphorus and chromium by bismuth impregnated biochar: Adsorption mechanism and depleted adsorbent utilization. Chemosphere, 164: 32-40. 